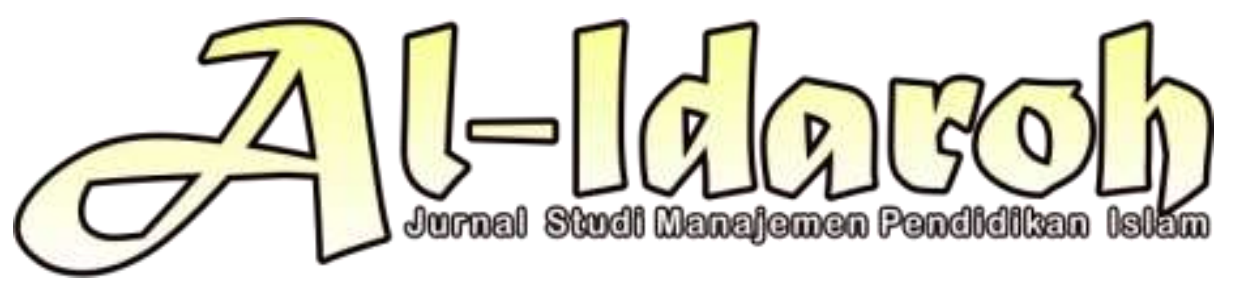

\title{
MANAJEMEN KEPESERTA DIDIKAN DALAM PENGEMBANGAN KECERDASAN INTELEKTUAL DAN EMOSIONAL PESERTA DIDIK
}

\author{
Waras Didik Susanto \\ Institut Pesantren Kh. Abdul Chalim Pacet Mjokerto, Indonesia \\ Email: warasdidik1977@gmail.com \\ Tatik Swandari \\ Institut Pesantren Kh. Abdul Chalim Pacet Mjokerto, Indonesia \\ Email: tatikswandari12@gmail.com
}

\begin{abstract}
This article aims to describe and analyze student recruitment and development in in increasing of students' intellectual - emotional intelligence at MTs Ma'arif Randegansari Driyorejo Gresik. This article uses a qualitative approach with the type of case study research. The location of this research is MTs. Ma'arif Randegansari Driyorejo Gresik. data was collected using observation, structured and in-depth interviews and documentation. The analysis uses data reduction techniques, data presentation and conclusion drawing. to check the validity, the researcher used triangulation. Based on the process of data collection and analysis. The researcher concludedseveral things, namely: (1) Recruitment of new students at MTS. Ma'arif Randegansari Driyorejo Gresik: active recruit approach with Walks-ins; The candidate of students come to MTs Ma'arif Randegansari Driyorejo Gresik, and registered, then rite-ins; The candidate of students come to MTs and their parents write on a registration form. Implementation of Matsama: developing the new students' cognition in terms of divergent and convergent thinking skills. (2) Placement of students in MTS. Ma'arif Randegansari Driyorejo Gresik,: Abjad system; placement of learning in the classroom (intracurricular), The Dual Progress Plan Grouping; dividing students into several groups who have heterogeneous intelligence and are guided by a teacher (Self-Contained Classroom). Fingerprint system; placement of students in the development of talents and interests (extracurricular). (3) Student development in increasing of students' intellectual-emotional intelligence (a) intracurricular; learning in the classroom, (b) extracurricular; quark science Olympic tutoring mathematics, English, tahfids, scouts, guidance programs, discipline, reflection, and mubasabah.
\end{abstract}

Keywords: Student Management, Emotional Intelligence, Intellectual Intelligence. 


\section{Pendahuluan}

Peserta didik merupakan aset vital bagi bangsa, maka perlu dikelola dengan baik. Semua pihak terlebih madrasah harus memberikan perhatian penuh kepada peserta didik dalam rangka mengembangkan, bakat serta potensi yang dimiliki ${ }^{1}$. Hal ini sesuai dengan tujuan pendidikan nasional yang berfungsi mengembangkan kemampuan dan membentuk watak serta peradaban bangsa yang bermartabat dalam rangka mencerdaskan kehidupan bangsa, bertujuan untuk berkembangnya potensi peserta didik agar menjadi manusia yang beriman dan bertakwa kepada Tuhan Yang Maha Esa, berakhlak mulia, berilmu, sehat, cakap, mandiri, kreatif, dan menjadi warga Negara yang demokratis serta bertanggung jawab².

Beberapa permasalahan intelektual peserta didik pada Madrasah Tsanawiyah (MTs) diantaranya adalah kurang memahami materi yang diajarkan, peserta didik yang mengalami gangguan dengan ingatannya atau sering lupa dengan materi pelajaran, peserta didik yang lambat belajar, peserta didik yang mengalamai keterlambatan akademik, dan peserta didik yang tidak mampu mencapai tujuan belajar atau hasil belajar ${ }^{3}$. Pemerhati sektor pendidikan dari lembaga Wiratama Institute, Rahmawati Habie berpendapat bahwa saat ini dunia pendidikan di Indonesia mengalami krisis kecerdasan emosional. Gejala yang berkaitan dengan tingkah laku peserta didik ketika mengalami masalah emosional yang dapat mengganggu belajar peserta didik, antara lain adalah kemunduran kualitas kerja peserta didik secara tiba-tiba, sensitivitas terhadap kritik, perasaan tidak suka, iri hati akan keberhasilan peserta didik-peserta didik lain, variasi perasaan ekstrim dari hari ke hari, membuka rahasia atau berbohong agar peserta didik lain mengalami kesulitan atau untuk memperlihatkan bahwa dirinya lebih baik dari peserta didik-peserta didik lain, menunjukkan hubungan sosial yang buruk dengan kelompoknya, tidak ada usaha

\footnotetext{
${ }^{1}$ Sudirman Anwar, Management Of Student Development (Tembilahan: Indragiri TM, 2015), 23.

${ }^{2}$ Diana Susilawati Sj, Muhammad Anas Maarif, and Afif Zamroni, "Strategi Pengembangan Program Pembelajaran Pendidikan Agama Islam Sekolah: The Development Strategy of Islamic Religious Education Learning Programs," Tafkir: Interdisciplinary Journal of Islamic Education 2, no. 1 (January 10, 2021): 25

${ }^{3}$ Achmad Krisbiyanto, "Efektifitas Kepemimpinan Kepala Madrasah Terhadap Mutu Pendidikan MTsN 2 Mojokerto," Nidhomul Haq: Jurnal Manajemen Pendidikan Islam 4, no. 1 (March 10, 2019): 60
} 
untuk melakukan atau mencoba sesuatu yang baru dan berbeda, dan tidak mampu mengontrol tingkah laku diri ${ }^{4}$.

Kecerdasan emosional peserta didik pada pendidik Madrasah Tsanawiyah (MTs) yang rendah juga ditunjukkan dengan banyaknya kasus perkelahian antara peserta didik, bahkan perkelahian tersebut hingga melibatkan kelompok, bukan hanya personal ${ }^{5}$. Peserta didik juga sulit untuk menahan diri ketika melakukan antrian, seringkali terjadi percekcokan di tempat wudlu dan kantin. Itu artinya peserta didik tersebut belum bisa membina hubungan baik dengan individu lain, dan kemampuan membina hubungan baik merupakan salah satu unsur pokok kecerdasan emosional seseorang ${ }^{6}$.

Berdasarkan fakta di atas, maka harus ada upaya penanggulangan perilaku menyimpang dan mendukung prestasi peserta didik. Di antaranya orang tua, madrasah dan masyarakat hendaknya menciptakan lingkungan yang kondusif, memotivasi peserta didik untuk senantiasa mengisi waktu luang dengan kegiatan yang bermanfaat ${ }^{7}$. Keinginan dan minat peserta didik harus dikoordinir dan dibimbing dengan baik agar menghasilkan kreatifitas yang bermanfaat. Jika tidak demikian maka mereka akan lebih condong kepada hal-hal yang negatif ${ }^{8}$.

Proses pembimbingan keinginan dan minat di lembaga pendidikan atau madrasah yang dapat mengembangkan potensi dan kecerdasan peserta didik dinamakan manajemen kepeserta didikan'. Manajemen kepeserta didikan adalah pengelolaan seluruh proses kegiatan peserta didik di madrasah. Atau dengan kalimat lain sebuah usaha pengelolaan dan pembimbingan minat dan kecerdasan peserta

${ }^{4}$ Slameto, Belajar dan faktor-faktor yang mempengarubinya (Jakarta: Bina Aksara, 1988), 44.

${ }^{5}$ Arin Muflichatul Matwaya and Ahmad Zahro, "Konsep Spiritual Quotient Menurut Danah Zohar Dan Ian Marshall Dalam Perspektif Pendidikan Islam," Attadrib: Jurnal Pendidikan Guru Madrasah Ibtidaiyah 3, no. 2 (September 29, 2020): 41-48

${ }^{6}$ Muhammad Anas Maarif, Muhammad Husnur Rofiq, and Nur Silva Nabila, "Pendidikan Pesantren Berbasis Multiple Intellegences (Kecerdasan Majemuk)," Tafkir: Interdisciplinary Journal of Islamic Education 1, no. 1 (2020): 1-19

${ }^{7}$ Wenefrida Yarso, Yohanes Bahari, and Yusuf Ibrahim, "Penanggulangan Kenakalan Peserta didik Kelas Xi Jurusan Pemasaran Sekolah Menengah Kejuruan Bhineka Tunggal Ika Pontianak," Jurnal Pendidikan dan Pembelajaran Khatulistiwa 2, no. 6 (June 21, 2013), 33

${ }^{8}$ Eva Imania Eliasa et al., "Pedagogy of Peacefulness as an Effort of Peaceful Education at School," Indonesian Journal of Educational Counseling 3, no. 2 (July 23, 2019): 85-96

${ }^{9}$ Zainal Aqib, Menjadi guru profesional berstandar nasional: memuat standar nasional pendidikan UURI no. 20/2003 (Sisdiknas), UURI no. 14/2005 (guru dan dosen), PPRI no. 19/2005 (standar nasional pendidikan), PPRI no. 74/2008 (guru), delapan permendiknas (standar nasional pendidikan), Permendiknas no. 10/2009 (sertifikasi bagi guru dalam jabatan), Permendiknas no. 36/2007 (penyaluran tunjangan profesi bagi guru), Permendiknas no. 39/2008 (pembinaan kepeserta didikan) (Yrama Widya, 2009). 
didik melalui berbagai kegiatan yang dilaksanakan di madrasah mulai dari peserta didik masuk hingga lulus. Bila minat dan keinginan peserta didik mendapatkan bimbingan yang tepat, maka kecerdasan peserta didik akan berkembang hingga memiliki kompetensi yang menjadi keunggulannya ${ }^{10}$.

MTs. Ma'arif NU yang berada di desa Randegansari, kecamatan Driyorejo, kabupaten Gresik merupakan madrasah yang berupaya mendukung kecerdasan maupun potensi peserta didik, dengan melaksanakan kegiatan kurikuler dan ekstrakurikuler. Keadaan intelektual peserta didik dari MTs. Ma'arif NU cukup bervariasi beberapa diantaranya ditandai dengan peserta didik yang memiliki pengetahuan umum yang luas, menguasai bahasa Arab dan bahasa Inggris, menguasai pengetahuan matematika, dan memiliki pengetahuan dalam bidang tahfidzil quran atau hafalan al-Quran. Adapun keadaan emosional peserta didik dari MTs. Ma'arif NU juga bervariasi seperti peserta didik memiliki rasa percaya diri yang besar, menghargai waktu dengan sampai ke madrasah 10 menit sebelum bel masuk berbunyi, dan mempunyai jiwa pemimpin ditandai dengan semangat dalam belajar dan memiliki etos kerja yang kuat dalam belajar

Kegiatan kurikuler dilaksanakan pada saat jam pelajaran dengan terus membimbing dan memotivasi peserta didik dalam proses pembelajaran. Sementara untuk kegiatan ekstrakurikuler dilaksanakan di luar jam pelajaran meliputi olimpiade matematika, sains, bahasa Inggris, tahfidz, tartil, qiroah, music, voli, futsal, hadrah, pramuka, kaligrafi, silat, catur, dan paskibara. Beberapa kegiatan ekstrakurikuler mengarah pada pengembangan kecerdasan intelektual peserta didik yaitu les olimpiade matematika, sains, bahasa inggris, tahfidz, tartil, dan qiroah. Selain itu untuk mengembangkan kecerdasan emosional, MTs. Ma'arif NU mempunyai tim tersendiri dalam menangani dan membimbing masalah emosional peserta didik. Tim ini di bawah tanggung jawab wakil kepala madrasah urusan kepeserta didikan.

Hasil dari usaha yang dilakukan oleh madrasah dalam pengembangan kecerdasan peserta didik, maka prestasi-prestasi yang diraih peserta didik terus bertambah. Prestasi yang pernah diraih di antaranya juara pertama Olimpiade bahasa Inggris KSM (Kompetisi Sains Madrasah) Kabupaten Gresik, juara dua Fisika KSM

${ }^{10}$ Ary Gunawan, Administasi Sekolah (Administrasi Pendidikan Mikro) (Jakarta: Rineka Cipta, 2002) 34. 
Kabupaten Gresik, juara tiga IPS terpadu Kabupaten Gresik, juara 2 matematika KSM Kabupaten Gresik Berangkat dari penjelasan di atas, maka judul tesis ini adalah: "Manajemen Kepeserta didikan dalam Pengembangan Kecerdasan Intelektual Emosional Peserta Didik di Madrasah Tsanawiyah Ma'arif NU Randegansari, Driyorejo, Gresik".

\section{Hasil dan Diskusi}

1. Rekrutmen Kepeserta didikan dalam Pengembangan Kecerdasan Intelektual Emosional Peserta Didik di Madrasah Tsanawiyah Ma'arif NU

\section{Randegansari}

Rekrutmen sebagaimana yang diungkapkan pada bab dua diartikan sebagai serangkaian kegiatan yang dimulai ketika sebuah lembaga memerlukan peserta didik baru ${ }^{11}$ dan membuka pendaftaran peserta didik baru sampai mendapatkan calon peserta didik yang diinginkan. Dalam hal ini, Madrasah Tsanawiyah NU Randegansari sudah melaksanakan proses rekrutmen setiap menjelang tahun ajaran baru.

Sebelum pelaksanaan rekrutmen peserta didik baru dimulai, MTs. Ma'arif NU selaku lembaga penyelenggara rekrutmen, melakukan penetapan mengenai jumlah peserta didik yang dibutuhkan. Pada tahun ajaran baru ini, MTs. Ma'arif NU menyiapakan empat kelas yang mana setiap kelas akan diisi oleh 28 peserta didik baru dalam satu kelas yang akan dipegang oleh satu guru. Setelah penetapan peserta didik yang dibutuhkan, maka segera merancang program kerja kepeserta didikan MTs. Ma'arif NU selama satu tahun kedepan. Hal ini sesuai dengan langkah awal dalam manajemen kepeserta didikan yaitu analisis kebutuhan peserta didik yang didalamnya terdapat penetapan peserta didik yang dibutuhkan oleh lembaga pendidikan madrasah ${ }^{12}$. Kegiatan yang dilakukan dalam analisis kebutuhan yaitu merencanakan jumlah peserta didik yang akan diterima dan

\footnotetext{
${ }^{11}$ Mizanul Hasanah, "Rekrutmen Dan Seleksi Tenaga Pendidikan (Guru) Untuk Meningkatkan Kualitas Pendidikan Di SMA Unggulan Berbasis Pesantren Amanatul Ummah Pacet," Al-Tarbawi Al-Haditsab: Jurnal Pendidikan Islam 5, no. 1 (June 27, 2020), 34

${ }^{12}$ Daniel Goleman, Emotional Intelligence: Why It Can Matter More Than IQ (New York: Toronto: Random House Publishing Group, 2012) 88
} 
menyusun program kegiatan kepeserta didikan. Analisis kebutuhan sesuai dengan relationship management dalam kecerdasan intelektual dan emosional ${ }^{13}$.

Diantara metode yang dipakai dalam pelaksanaan rekrutmen peserta didik baru di MTs. Ma'arif NU yaitu penyebaran pamflet, selebaran, brosur, dan pemasangan spanduk. Selain itu juga dengan melaksanakan lomba-lomba yang dapat diikuti oleh peserta didik dari SD/MI. Dalam pelaksanaan Try Out SD/MI ada penampilan berbagai kegiatan unggulan MTs. Ma'arif NU seperti ekstrakurikuler dan kegiatan pembelajaran di kelas yang mana itu dapat menjadi pertimbangan para wali murid untuk kegiatan yang akan dipilih ketika buah hatinya belajar di MTs. Ma'arif NU. Cara yang paling utama marketing di MTs. Ma'arif NU yaitu dari peserta didik MTs. Ma'arif NU beserta wali muridnya. Hal ini sesuai dengan metode dalam penerimaan peserta didik baru yaitu pengiklanan, rekomendasi dari orang lain, dan melalui perlombaan ${ }^{14}$.

Adapun penerimaan peserta didik bertujuan memberi kesempatan yang seluas-luasnya bagi warga Negara usia madrasah agar memperoleh layanan pendidikan yang sebaik-baiknya. Penerimaan peserta didik baru harus berlandaskan pada azas-azas tertentu. Seperti penerimaan peserta didik baru di MTs. Ma'arif NU bersifat terbuka dan dapat diketahui oleh seluruh lapisan masyarakat serta pelaksanaannya berdasarkan pada aturan yang berlaku. Dalam hal ini, rekrutmen peserta didik baru di MTs. Ma'arif NU berasaskan pada sifat keterbukaan, objektivitas, transparansi dan dapat dipertanggungjawabkan. Sedangkan untuk usia minimal yang diterima dalam penerimaan peserta didik baru di MTs. Ma'arif NU yaitu itu usia maksimal 15 tahun. Ini sesuai dengan persyaratan calon peserta didik kelas 7 Madrasah Tsanawiyah (MTs) wajib diterima.

Rekrutmen peserta didik di madrasah pada hakikatnya merupakan proses pencarian, penentuan, dan penarikan pelamar yang akan menjadi peserta didik di

${ }^{13}$ Ivan Riyadi, "Integrasi Nilai-Nilai Kecerdasan Emosional Dalam Kurikulum Pendidikan Agama Islam Di Sma: Perspektif Daniel Goleman,” Hunafa: Jurnal Studia Islamika 12, no. 1 (June 18, 2015): 141-163

${ }^{14}$ Veithzal Rivai, Manajemen sumber daya manusia untuk perusahaan: dari teori ke praktik (Rajawali Pers, 2009) 65. 
madrasah $^{15}$. Tahapan maupun langkah-langkah dalam rekrutmen peserta didik baru di MTs. Ma'arif NU sudah terencana sebelumnya dan seluruh rangkaian dari penerimaan peserta didik baru sudah disiapkan sebelumnya dengan baik. Hal ini sesuai dengan definisi penerimaan peserta didik baru itu sendiri yakni salah satu kegiatan yang pertama dilakukan sehingga harus dikelola sedemikian rupa supaya kegiatan belajar mengajar sudah dapat dimulai pada hari pertama setiap tahun ajaran baru ${ }^{16}$.

Rekrutmen peserta didik dalam suatu lembaga pada hakikatnya merupakan proses pencarian dan penentuan calon peserta didik yang melamar di suatu lembaga pendidikan yang akan menjadi peserta didik di lembaga tersebut. Sebelum pelaksanaan rekrutmen peserta didik baru, harus sudah direncanakan tahapan atau langkah-langkah dalam penerimaan peserta didik baru. Adapun langkah-langkah dalam penerimaan peserta didik baru di Madrasah Tsanawiyah Ma'arif NU Randegansari yaitu pertama rapat mengenai Penerimaan Peserta Didik Baru. Kedua adalah pemilihan koordinator PPDB. Ketiga pembentukan panitia PPDB. Selanjutnya pembuatan pamphlet, brosur, selebaran, dan spanduk. Selanjutnya pemasangan spanduk di beberapa titik dan penyebaran pamphlet, brosur, dan selebaran di kegiatan yang dilaksanakan di MTs. Ma'arif NU dan penyebaran di beberapa SD/MI. Selanjutnya yaitu pelaksaksanaan pendaftaran peserta didik baru disertai dengan persyaratan pendaftaran yang disusul dengan pendaftaran ulang peserta didik baru. Hal ini sesuai dengan langkah-langkah penerimaan peserta didik baru menurut Eka Prihatin yaitu pertama pembentukan panitia penerimaan peserta didik baru yang didalamnya membahas mengenai pelaksanaan PPDB, penunjukan ketua panitia PPDB, dan membentuk anggota PPDB. Kedua, rapat penentuan peserta didik baru didalamnya membahas mengenai kegiatan apa saja yang akan dilaksanakan dalam PPDB. Ketiga, pembuatan, pengiriman/pemasangan pengumuman mengenai dimulainya penerimaan peserta didik baru di MTs. Ma'arif NU. Keempat yaitu pendaftaran calon peserta didik baru yang terdiri dari dua gelombang dan mengisi formulir dan mendaftar di loket

${ }^{15} \mathrm{Ali}$ Mudlofir, Pendidik profesional: konsep, strategi, dan aplikasinya dalam peningkatan mutu pendidikan di Indonesia (Jakarta: RajaGrafindo Persada, 2012) 56.

${ }^{16}$ Suharsini Arikunto, Organisasi dan administrasi: pendidikan teknologi dan kejuruan (Jakarta: Rajawali, 1990) 9. 
pendaftaran yang telah ditentukan. Dan yang terakhir yaitu daftar ulang peserta didik baru dengan memenuhi persyaratan dan kelengkapan yang diminta oleh madrasah yang juga terdiri dari dua gelombang ${ }^{17}$.

Berkenaan dengan seleksi peserta didik baru, yang mana proses seleksi merupakan rangkaian tahap-tahap khusus yang digunakan untuk memutuskan calon peserta didik mana yang akan diterima. Akan tetapi, di Madrasah Tsanawiyah Ma'arif NU Randegansari tidak melaksanakan seleksi seperti yang ada pada lembaga tingkat menengah maupun tingkat atas. Karena MTs. Ma'arif NU merupakan pendidikan di tingkat pertama yang mana pendidikan pada tingkat pertama tidak diperbolehkan untuk melaksanakan seleksi. Jadi untuk seluruh peserta didik baru yang mendaftar di MTs. Ma'arif NU langsung diterima di MTs. Ma'arif NU yang mana itu memenuhi kualifikasi untuk menjadi peserta didik di MTs. Ma'arif NU. Hal ini sesuai dengan definisi seleksi peserta didik baru yaitu kegiatan pemilihan calon peserta didik yang dianggap memenuhi kualifikasi untuk menjadi peserta didik ${ }^{18}$.

Ketika peserta didik baru sudah dinyatakan di MTs. Ma'arif NU, maka mereka saat memasuki lingkungan baru akan mengalami kesulitan, baik disebabkan oleh situasi maupun karena praktek dan prosedur yang berbeda dari madrasah mereka yang sebelumnya. Kesulitan itu kalau tidak diatasi dapat menimbulkan ketegangan jiwa. Agar tidak mengalami ketegangan, segenap pendidik akan memberi penjelasan-penjelasan tentang hal-hal yang berkaitan dengan lembaga MTs. Ma'arif NU. Maka dari itu, di MTs. Ma'arif NU diadakan kegiatan Masa Orientasi Peserta didik untuk peserta didik baru dalam rangka mengenalkan madrasah. Hal ini sesuai dengan definisi Masa Orientasi Peserta didik menurut Suwardi dan Daryanto yaitu suatu kegiatan untuk mengantar peserta didik ke jenjang pendidikan baru yang menjembatani peserta didik baru mengenali berbagai kekhususan dari jenjang pendidikan barunya, baik berupa lingkungan fisik, lingkungan sosial, maupun isi dan cara belajar yang berbeda

${ }^{17}$ Eka Prihatin, Manajemen Peserta Didik (Bandung, Indonesia: Alfabeta, 2011) 77.

${ }^{18}$ Hendyat Soetopo, Pengantar Operasional Administrasi Pendidikan (Jakarta: Usaha Nasional, 1982), 88. 
dengan lingkungan sebelumnya ${ }^{19}$. Proses rekrutmen peserta didik baru di MTs. Ma'arif NU yang telah dijelaskan sesuai dengan kecakapan dasar kecerdasan intelektual-emosioanal yaitu self awareness, self manajement, dn self esteem ${ }^{20}$.

MTs. Ma'arif NU melaksanakan kegiatan Masa Orientasi Peserta didik (MOS) yang dinamakan Matsama (Masa Ta'aruf Peserta didik Madrasah) dalam tiga hari pertama masuk Madrasah. Matsama dilaksanakan oleh panitia yang di tunjuk. Kegiatan untuk hari pertama adalah pembagian kelas 7 dan pengenalan Kepala Madrasah dan Dewan Guru MTs. Ma'arif NU. Hari kedua adalah pengenalan lingkungan madrasah. Hari ketiga adalah penanaman konsep akhlak dan pengenalan mapel serta kewajiban peserta didik di madrasah. Kegiatan selama tiga hari tersebut merupakan kegiatan yang harus diikuti oleh peserta didik baru berupa perkenalan dengan para guru dan staf madrasah, perkenalan dengan peserta didik lama, penjelasan tentang tata tertib madrasah, serta mengenal dan meninjau fasilitas-fasilitas madrasah.

Orientasi peserta didik baru juga dapat dikatakan sebagai kegiatan yang merupakan salah satu bagian dalam rangka proses penerimaan peserta didik baru. Masa orientasi peserta didik pun tak lepas dari tujuan pelaksanaanya tersebut. Adapun tujuan diadakannya Masa Orientasi Peserta didik di MTs. Ma'arif NU adalah peserta didik bisa menempatkan dirinya dengan beradaptasi di lingkungan madrasah. Selanjutnya agar peserta didik mengetahui seluruh sarana maupun prasarana yang ada di MTs. Ma'arif NU, mengenali lingkungan MTs. Ma'arif NU, menjadi semakin percaya diri dalam belajar, mengatahui kewajibannya dalam belajar, dan mengetahui seluruh peraturan yang ada di MTs. Ma'arif NU. Hal ini sesuai dengan tujuan pelaksanaan Masa Orientasi Baru menurut Ali Imron yaitu agar peserta didik mengetahui situasi dan kondisi di madrasah, agar peserta didik mengetahui budaya yang tumbuh dan berkembang di madrasah, agar peserta didik mengetahui berbagai sarana prasarana yang ada di madrasah, agar peserta didik mengetahui unit-unit kegiatan yang ada dan tumbuh di madrasah, agar peserta

\footnotetext{
${ }^{19}$ Muhammad Farid and Daryanto, Konsep Dasar Manajemen Pendidikan Di Sekolah. (Yogjakarta: Gava Media, 2013).56

${ }^{20}$ Meirav Hen and Marina Goroshit, "Academic Procrastination, Emotional Intelligence, Academic Self-Efficacy, and GPA: A Comparison Between Students With and Without Learning Disabilities," Journal of Learning Disabilities 47, no. 2 (March 1, 2014): 116-124
} 
didik mengetahui berbagai peraturan yang ada dan berlaku dimadrasah. Sekaligus mengetahui sangsi yang akan diberikan kepada peserta didik yang melanggar peraturan, serta agar peserta didik mengetahui pimpinan, guru-guru, dan pegawai lainnya yang ada dimadrasah ${ }^{21}$.

Kegiatan Matsama (Masa Ta'aruf Madrasah) MTs. Ma'arif NU sesuai dengan cara meningkatkan kecerdasan intelektual-emosional peserta didik yaitu membuat dialog antar peserta didik dengan guru, dan antar peserta didik dengan peserta didik lain, menanamkan kata-kata baik, mengasah empati, dan belajar berhubungan dengan orang lain.

\section{Penempatan Kepeserta didikan Dalam Pengembangan Kecerdasan} Intelektual Emosional Peserta Didik di Madrasah Tsanawiyah Ma'arif NU

\section{Randegansari}

Ruangan Kelas merupakan sarana Primer dalam pembelajaran, setiap madrasah wajib memiliki ruang belajar yang dijadikan sebagai tempat pelajar menuntut ilmu pengetahuan, bagaimana penempatan peserta didik dalam ruang belajar, apakah harus dibedakan antara peserta didik yang memiliki kemampuan tinggi dengan peserta didik yang hanya mempunyai intregritas dibawah rata-rata.

Kegiatan penempatan peserta didik yang dilaksanakan bagi peserta didik Pengelompokan atau lazim dikenal dengan grouping didasarkan atas personal/individu bahwa disamping peserta didik tersebut mempunyai kesamaan, juga mempunyai perbedaan. Hal ini akan memudahkan peserta didik untuk ditempatkan dalam kelompok belajar peserta didik. Pengelompokan peserta didik pada umumnya dilakukan melalui pembagian kelas.

Penempatan peserta didik atau lazim dikenal dengan pengelompokan peserta didik di MTs. Ma'arif NU dilaksanakan berdasarkan abjad nama setiap peserta didik. Pengelompokan peserta didik ini dilakukan berdasarkan pula pada perbedaan-perbedaan yang ada dalam setiap diri peserta didik. Perbedaan dalam hal kemampuan maupun kepribadian tidak menjadikan penempatan peserta didik juga berbeda. Dengan perbedaan, maka peserta didik akan terbiasa dan bisa mengambil setiap pelajaran dalam setiap perbedaan. Jadi dapat dikatakan bahwa

${ }^{21}$ Ali Imron, Manajemen Peserta Didik Berbasis Sekolah (Bandung: Bumi Aksa, 2012) 56. 
penempatan peserta didik di MTs. Ma'arif NU dilaksanakan sesuai dengan teori dari Ali Imron yaitu layanan yang berbeda secara individual demikian dianggap kurang efisien, maka dilakukan pengelompokan berdasarkan persamaan dan perbedaan peserta didik. Dengan perkataan lain, pengelompokan di MTs. Ma'arif NU adalah konvergensi dari pengajaran sistem klasikal dan sistem individual.

Hal tersebut dapat dikatakan pula bahwa seluruh peserta didik ditempatkan pada kelas yang dimana akan diampu oleh satu guru dengan perbedaan seluruh peserta didik dalam satu kelompok kelas. Adapun untuk kelompok kelas yang lain akan ditempatkan pula pada guru yang lain. Dalam hal ini MTs. Ma'arif NU memakai penempatan peserta didik berdasarkan pada penempatan sekelompok peserta didik pada seorang guru (self-contained classroom) yang mana self-contained classroom adalah penempatan sekelompok peserta didik oleh seorang guru. Sedangkan sekelompok peserta didik yang lain ditempatkan pada guru lainnya. Selain itu, penempatan peserta didik di MTs. Ma'arif NU dapat dikatakan menggunakan sistem pengelompokan kemajuan rangkap (the dual progress plan grouping) yang mana sistem pengelompokan ini dimaksudkan untuk mengatasi perbedaan- perbedaan kemampuan individual disetiap umur dan setiap tingkat.

Penempatan peserta didik di MTs. Ma'arif NU dapat dikatakan berdasarkan abjad nama dalam setiap peserta didik. Akan tetapi dalam pengelompokan kelas dalam pembelajaran mengaji metode Ummi dilaksanakan berdasarkan kemampuan setiap peserta didik. Dari keterangan tersebut dapat dijelaskan bahwa penempatan peserta didik di MTs. Ma'arif NU untuk kelompok kelas mengaji metode Ummi dilaksanakan berdasarkan kemampuan yang ada dalam setiap peserta didik. Sebelum dikelompokkan, setiap peserta didik melaksanakan tes terlebih dulu oleh koordinator Ummi MTs. Ma'arif NU. Pengelompokan berdasarkan kemampuan bertujuan agar kemampuan yang ada dalam setiap individu peserta didik semakin meningkat.

Penempatan peserta didik yang bertujuan untuk mengetahui bakat dan kepribadian peserta didik dengan menggunakan angket dilaksanakan di awal tahun ajaran baru khusus untuk kelas 7 . Hasil dari angket tersebut dapat dijadikan sebuah pengarahan kegiatan bakat minat oleh guru terhadap peserta didik. Guru 
hanya sebatas mengarahkan akan tetapi semua kembali kepada peserta didik untuk mengambil kegiatan apa yang sesuai dengan minatnya.

Penempatan peserta didik di MTs. Ma'arif NU sesuai dengan pengembangan kecerdasan intelektual emosional peserta didik yaitu mengelola emosi, mengasah empati, belajar berhubungan dengan orang lain, dan juga memotivasi orang lain. Kehadiran peserta didik dan ketidakhadiran peserta didik MTs. Ma'arif NU ditulis dalam buku absensi setiap kelas. Pada akhir semester seluruh rekapan kehadiran dan ketidak hadiran peserta didik akan dicatat di Raport peserta didik dan dilaporkan kepada orang tua peserta didik pada akhir semester. Ketidakhadiran yang akan mempengaruhi proses belajar peserta didik dan tidak dapat memenuhi target belajar peserta didik. Hal ini sesuai dengan teori dari Eka Prihatin yang menjelaskan bahwa kehadiran disebut juga presensi peserta didik. Presensi mengandung dua arti, yaitu masalah kehadiran dimadrasah dan ketidakhadiran dimadrasah. Hal itu merupakan hal yang penting dalam pengelolaan peserta didik dimadrasah, karena berhungan erat dengan prestasi belajar peserta didik. Kehadiran peserta didik MTs. Ma'arif NU sesuai dengan pengembangan kecerdasan intelektual-emosional peserta didk untuk memotivasi diri sendiri dalam kesadaran belajar dan introspeksi diri.

\section{Pengembangan Kepeserta didikan dalam Pengembangan Kecerdasan} Intelektual Emosional Peserta Didik di Madrasah Tsanawiyah Ma'arif NU

\section{Randegansari}

Tahap selanjutnya dalam manajemen kepeserta didikan adalah pengembangan peserta didik. Kegiatan pembinaan dan pengembangan peserta didik dilaksanakan untuk memproses seluruh peserta didik untuk menjadi manusia yang diharapkan sesuai dengan tujuan pendidikan. Pembinaan dan pengembangan peserta didik dilakukan sehingga anak mendapatkan bermacam-macam pengalaman belajar untuk bekal kehidupan yang akan datang. Untuk pengetahuan atau pengalaman belajar ini peserta didik harus melakukan bermacam-macam kegiatan.

Pembinaan dan pengembangan peserta didik selain difokuskan pada peningkatan kecerdasan dan kemampuannya, juga perlu memperhatikan perkembangan psikologis yang dialaminya, serta disesuaikan dengan kebutuhan 
dan keinginan peserta didik itu sendiri. Seperti di MTs. Ma'arif NU, pelaksanaan pengembangan peserta didik bertujuan mengembangkan potensi yang sesuai dengan bakat minat peserta didik dan membentuk kepribadian peserta didik yang lebih baik dan berakhlak mulia.

Tujuan adanya pengembangan peserta didik tersebut sesuai dengan teori Agus Wibowo ${ }^{22}$ yang menyatakan bahwa tujuan pengembangan peserta didik adalah: 1) Mengembangkan potensi peserta didik secara optimal dan terpadu yang meliputi bakat, minat dan keterampilan. 2) Memantapkan kepribadian peserta didik untuk mewujudkan ketahanan madrasah sebagai lingkungan pendidikan sehingga terhindar dari usaha dan pengaruh negatif dan bertentangan dengan tujuan pendidikan. 3) Mengaktualisasikan potensi peserta didik dalam mencapai prestasi unggulan sesuai bakat minat. 4) Menyiapkan peserta didik agar menjadi warga masyarakat yang berakhlak mulia, demokratis, dan menghormati hak-hak manusia ${ }^{23}$.

Pengembangan peserta didik dalam pembelajaran didalam kelas dimulai dengan membuat perencanaan terhadap apa yang akan dilaksanakan guru dalam pembelajaran $^{24}$. Di MTs. Ma'arif NU, guru sebelum memasuki kelas sudah menentukan apa materi yang akan disampaikan. Dengan jumlah peserta didik yang dalam suatu kelas, guru bisa mengelola kelas dengan baik dalam waktu 2 jam pelajaran agar peserta didik dalam satu kelas juga memahami materi pembelajaran yang telah berlangsung. Guru juga menentukan berbagai kebutuhan belajar yang sesuai dengan berbagai karakter belajar peserta didik. Ini merupakan suatu analisis kebutuhan dalam perancangan pengembangan peserta didik. Apa yang direncanakan sebelumnya yaitu guru menentukan materi yang akan di sampaikan beserta waktu yang diperlukan dengan jumlah peserta didik yang ada dalam suatu kelas.

Tujuan pembelajaran tersebut adalah untuk mengembangkan potensi atau kecerdasan peserta didik dalam ranah kognitif, afektif, maupun psikomotorik.

\footnotetext{
${ }^{22}$ Agus Wibowo, Manajemen Pendidikan Karakter Di Sekolah: Konsep Dan Pratik Implementasi (Semarang: Diterbitkan atas kerjasama Fak Tarbiyah IAIN Walisongo Pustaka Pelajar, 2013) 112.

${ }^{23}$ Agus Wibowo and Gunawan, Pendidikan karakter berbasis kearifan lokal di sekolah: konsep, strategi, dan implementasi (Yogyakarta: Pustaka Pelajar, 2015)124.

${ }^{24}$ Hamzah B. Uno, Perencanaan Pembelajaran (Jakarta: Bumi Aksara, 2007), 45
} 
Selain itu, peserta didik juga dapat memahami semua materi yang disampaikan oleh guru dan pada akhirnya mereka bisa menerapkan materi pelajaran dalam kehidupan sehari-hari. Adapun tujuan dari pembelajaran tersebut sesuai dengan teori dari Dick dan Carey yang mana tujuan harus menguraikan apa yang akan dapat dikerjakan atau diperbuat oleh peserta didik dan menyebutkan kriteria yang digunakan untuk menilai unjuk perbuatan peserta didik yang dimaksud pada tujuan $^{25}$.

Dalam pembelajaran, seorang guru juga harus menggunakan metode maupun strategi yang digunakan dalam proses belajar mengajar. Hal ini bertujuan agar dapat membantu proses belajar peserta didik, membantu menjawab semua kebutuhan peserta didik, dan mencari solusi dalam memecahkan masalah dengan memanfaatkan sejumlah informasi maupun media yang tersedia. Di MTs. Ma'arif NU, seluruh guru dalam pembelajaran menggunakan metode maupun strategi pembelajaran. Metode yang digunakan sangat bervariasi, disesuaikan dengan karakteristik materi yang akan disampaikan. Hal ini sesuai desain pembelajaran yang disusun untuk membantu proses belajar peserta didik, menganalisis kebutuhan peserta didik dalam pembelajaran, kemudian berupaya untuk membantu dalam menjawab kebutuhan tersebut.

Di MTs. Ma'arif NU setiap guru diwajibkan menyiapkan seluruh materi, metode, maupun strategi yang akan dilaksanakan dalam pembelajaran. Metode yang dipakai dalam proses belajar mengajar sangat bervariatif disesuaikan dengan karakteristik materi yang akan diajarkan seperti ceramah, diskusi, tanya jawab, demonstrasi maupun praktik. Hal ini sesuai dengan definisi dari metode pembelajaran sendiri yakni cara-cara atau teknik penyajian bahan pelajaran yang akan digunakan oleh guru pada saat menyajikan bahan pelajaran, baik secara individual atau secara kelompok.

Agar tercapainya tujuan pembelajaran yang telah dirumuskan, seseorang guru harus mengetahui berbagai metode. Seperti metode yang dipakai di MTs Ma’arif NU Randegansari sebagaimana metode pembelajaran yang diungkapkan

${ }^{25}$ W. Dick, L. Carey, and J.O. Carey, The Systematic Design of Instruction (Vital Source (for Pearson) VST $\mathrm{E}+\mathrm{p}, 2015), 67$ 
oleh Ahmad Sabri yaitu ${ }^{26}$ : Metode Ceramah: Metode ceramah yang dilaksanakan di MTs. Ma'arif NU yaitu dengan cara sseorang guru mengajar atau menyajikan materi melalui penuturan dan penerapan lisan kepada peserta didiknya di dalam proses belajar mengajar. Selanjutnya peserta didik dapat mengajukan beberapa pertanyaan terhadap materi yang belum mereka pahami kepada guru setelah guru selesai menjelaskan materi pelajaran.

Metode Diskusi: Di MTs. Ma'arif NU juga menggunakan metode diskusi yang mana diskusi merupakan suatu kegiatan belajar-mengajar yang membincangkan suatu topik atau masalah yang dilakukan oleh dua orang atau lebih (dapat guru dan peserta didik dan peserta didik yang lain). Dimana peserta diskusi yang berbincang memiliki perhatian yang sama terhadap topik atau masalah yang menjadi pokok pembicaraan, sehingga mendapatkan berbagai alternatif jawaban terhadap topik yang didiskusikan.

Metode Kelompok: Metode kelompok yang ada di MTs. Ma'arif NU merupakan format belajar- mengajar yang menitikberatkan kepada interaksi antara anggota yang satu dengan anggota yang lain dalam suatu kelompok guna menyelesaikan tugas-tugas belajar secara bersama-sama. Metode Campuran: Metode campuran juga diterapkan di MTs. Ma'arif NU. Metode campuran cara menyajikan bahan pelajaran di depan kelas melalui macam-macam kombinasi beberapa metode, misalnya; metode ceramah dengan metode diskusi bahkan dengan metode demonstrasi sekaligus dipakai/diterapkan dalam suatu kondisi pengajaran. Dalam praktiknya, metode campuran ini dapat diterapkan seorang guru dalam suatu situasi pengajaran di depan kelas, dengan persiapan yang baik dan sungguh-sungguh dalam mempraktikkan metode ini.

Dalam proses belajar mengajar di MTs. Ma'arif NU, seluruh peserta didik dianjurkan untuk selalu aktif dalam pembelajaran, sehingga kelas bisa hidup dengan keaktifan para peserta didik walaupun kadang guru masih menjadi pusat utama dalam pembelajaran. Karena itu, MTs. Ma’arif NU memakai jenis strategi pembelajaran strategi pembelajaran langsung (direct instruction) dan strategi pembelajaran interaktif (interactive intruction).

${ }^{26}$ Ahmad Sabri, Strategi Belajar Mengajar Micro Teaching/Ahmad Sabri (Jakarta: Quantum Teaching, 2010), 78. 
Guru banyak menemukan tipe-tipe peserta didik yang berbeda-beda dalam proses pembelajaran. Akan tetapi guru terus merangkul seluruh peserta didik dan mengusahakan peserta didik agar peserta didik bisa belajar dengan lancar. Selain itu guru juga mengajak peserta didik dan keluarga untuk diskusi perihal kekurangan peserta didik dan gurupun harus selalu memotivasi peserta didik dan agar peserta didik bisa menjadi lebih baik lagi sehingga peserta didikpun juga bisa memotivasi dirinya sendiri. Hal ini sesuai dengan teori peningkatan kecerdasan intelektual maupun emosional peserta didik yakni menanamkan kata-kata yang bisa memotivasi anak untuk meningkatkan belajar dan membuat anak semangat dalam belajar. Selain itu juga melakukan dialog atau diskusi yang mana dialog akan memiliki pengaruh terhadap kemampuan anak. Anak yang merasa rendah diri, akan mengalami pemiskinan intelektualitas. Sedangkan sebaliknya, dialog positif dapat meningkatkan keberhasilan anak meraih masa depan ${ }^{27}$.

Evaluasi peserta didik dilakukan dengan ujian tengah semester, ujian akhir semester, serta mengikuti berbagai kejuaraan perlombaan dan olimpiade. Sedangkan untuk pendataan kemajuan belajar peserta didik di MTs. Ma'arif NU dalam proses belajar mengajar di dalam kelas didata oleh guru dalam sebuah catatan khusus dan adapula dalam hasil rapot masing-masing peserta didik. Hal ini sesuai dengan teori evaluasi yang bermakna suatu proses yang sistematis untuk menentukan atau membuat keputusan sampai sejauh mana tujuan-tujuan pengajaran telah dicapai oleh peserta didik. Dengan hasil penilaian yang diperoleh guru akan dapat mengetahui peserta didik mana yang sudah berhasil menguasai bahan, maupun mengetahui peserta didik yang belum berhasil menguasai bahan ${ }^{28}$.

Kemajuan belajar peserta didik baik di dalam kelas maupun di luar kelas seperti dalam kegiatan ekstrakurikuler membutuhkan sebuah pendataan kemajuan prestasi peserta didik tersendiri. Pendataan kemajuan belajar peserta didik di MTs. Ma'arif NU dalam proses belajar mengajar di dalam kelas didata oleh guru dalam sebuah catatan khusus dan adapula dalam hasil raport masing-masing peserta didik. Sedangkan untuk pendataan kemajuan belajar peserta didik dalam kegiatan

\footnotetext{
${ }^{27}$ Abdul Majid, Belajar Dan Pembelajaran Pendidikan Agama Islam, 2nd ed. (Bandung: Remaja Rosdakarya, 2014)134.

28Zainal Arifin, "Evaluasi Pembelajaran," (Bandung: Remaja Rosdakarya, 2009), 45
} 
ekstrakurikuler dengan adanya catatan untuk setiap peserta didik oleh pembina ekstrakurikuler masing-masing. Selain itu juga dengan mengikutkan peserta didik dalam berbagai olimpiade dan perlombaan. Sebagaimana teori Oteng Sutisna yang menyatakan bahwa keberhasilan kemajuan untuk prestasi belajar para peserta didik memerlukan data yang otentik, terpercaya dan memiliki keabsahan. Data ini diperlukan untuk mengetahui dan mengontrol keberhasilan atau prestasi peserta didik.

Dalam mengembangkan intelektual maupun emosional peserta didik, selain pembelajaran didalam kelas, di MTs. Ma'arif NU juga mengembangkannya kegiatan ekstrakurikuler yang mana kegiatan tersebut merupakan kegiatan tambahan, di luar struktur program yang pada umumnya merupakan kegiatan pilihan. Ada banyak kegiatan ekstrakurikuler yang ada di MTs. Ma'arif NU mulai dari ekstrakurikuler wajib dan ekstrakurikuler pilihan. Hal ini seiring dengan konsep kecerdasan intelektual yang mana guru dalam mengembangkan kreativitas anak adalah dengan menyelenggarakan berbagai kegiatan.

Kegiatan ekstrakurikuler yang ada di MTs. Ma'arif NU sesuai dengan definisi dari kegiatan ekstrakurikuler itu sendiri yakni kegiatan tambahan yang berada di luar struktur program yang pada umumnya merupakan kegiatan pilihan $^{29}$. Kegiatan ekstrakurikuler sebagai pengembangan kecerdasan intelektual maupun kecerdasan emosional peserta didik di MTs. Ma'arif NU dibagi menjadi dua jenis yaitu kegiatan ekstrakurikuler wajib dan ekstrakurikuler pilihan. Ekstrakurikuler wajib seperti drumband, pramuka, renang, dan les wajib... kelas 9. Sedangkan untuk ekstrakurikuler pilihan berupa ekstrakurikuler pilihan akademik dan ekstrakurikuler pilihan olahraga dan seni. Hal ini sesuai dengan jenis ekstrkurikuler menurut Depdikbud yaitu jenis kegiatan esktarkurikuler yang bersifat lanjutan.

Dalam pengembangan melalui ekstrakurikuler, seseorang yang menjadi pembimbing maupun pembina harus memperhatikan seberapa besar pengaruh ekstrakurikuler tersebut terhadap kehidupan peserta didik. Apa yang diikuti oleh peserta didik seharusnya bisa menjadikan peserta didik lebih baik lagi baik dari segi

${ }^{29}$ Ayu Sundari, "Manajemen Kegiatan Ekstrakurikuler Dalam Meningkatkan Prestasi Non Akademik Peserta didik," Munaddhomah: Jurnal Manajemen Pendidikan Islam 2, no. 1 (April 21, 2021): 1-8 
intelektual maupun emosional mereka. Bagi pembina ekstrakurikuler di MTs. Ma'arif NU, seluruh kegiatan harus sudah dipersiapkan sebelumnya sehingga pelaksanaan dan target yang ingin diharapkan bisa tercapai. Pernyataan tersebut sesuai dengan teori Amir Daien yang dikutip oleh Eka Prihatin ${ }^{30}$, bahwa hal-hal yang perlu diketahui oleh pembina ekstrakurikuler adalah adanya perencanaan dan persiapan serta pembinaan yang telah diperhitungkan masak-masak sehingga program ekstrakurikuler mencapai tujuan. Selanjutnya yaitu kegiatan harus dapat meningkatkan pengayaan peserta didik yang beraspek kognitif, afektif, dan psikomotorik serta memberikan tempat serta penyaluran bakat dan minat sehingga peserta didik akan terbiasa dengan kesibukan-kesibukan yang bermakna.

Kegiatan ekstrakurikuler di MTs. Ma'arif NU dapat menjadi sebuah kemanfaatan yang lebih bagi peserta didik seperti wadah mengembangkan seluruh bakat dan minat dari peserta didik dan dapat mengembangkan kreatifitas peserta didik sehingga peserta didik merasa puas karena bakatnya bisa tersalurkan. Selanjutnya bisa menjadikan sebuah penyegaran otak bagi peserta didik dan peserta didikpun akan lebih semangat dalam menerima materi pelajaran selanjutnya. Kegiatan ekstrakurikuler juga bisa meningkatkan rasa tanggung jawab, kerjasama dan rasa percaya diri bagi peserta didik sehingga dalam bergaul dengan siapapun akan merasa percaya diri. Hal ini sebagaimana manfaat prinsipil dari partisipasi peserta didik terhadap kegiatan ekstrakurikuler yaitu dapat digunakan kemampuan berpikir kreatif dari para anggotanya, dapat mengendalikan nilai-nilai martabat manusia, motivasi serta membangun kepentingan bersama, lebih mendorong orang untuk bertanggung jawab, serta lebih memungkinkan untuk mengikuti perubahan-perubahan.

Kemajuan belajar peserta didik baik di dalam kelas maupun di luar kelas seperti dalam kegiatan ekstrakurikuler akan dibutuhkan sebuah pendataan kemajuan prestasi peserta didik tersendiri. Pendataan kemajuan belajar peserta didik di MTs. Ma'arif NU dalam proses belajar mengajar di dalam kelas didata oleh guru dalam sebuah catatan khusus dan dalam hasil raport masing-masing peserta didik. Sedangkan untuk pendataan kemajuan belajar peserta didik dalam

${ }^{30}$ Eka Prihatin, Manajemen Peserta Didik (Bandung, Indonesia: Alfabeta, 2011), 56 
kegiatan ekstrakurikuler dengan adanya catatan untuk setiap peserta didik oleh pembina ekstrakurikuler masing-masing. Selain itu dengan mengikutkan peserta didik dalam berbagai olimpiade dan perlombaan. Sebagaimana teori Oteng Sutisna yang menyatakan bahwa keberhasilan kemajuan untuk prestasi belajar para peserta didik memerlukan data yang otentik, terpercaya dan memiliki keabsahan. Data ini diperlukan untuk mengetahui dan mengontrol keberhasilan atau prestasi peserta $\operatorname{didik}^{31}$.

Bimbingan dan pembinaan disiplin peserta didik harus dilakukan oleh seluruh warga dalam sebuah lembaga pendidikan. Sebagaimana definisi bimbingan itu sendiri yakni pelayanan komprehensif yang tidak dapat dilakukan semata-mata satu orang saja, melainkan seluruh personal lembaga pendidikan perlu menunjang pelaksanaan itu agar tepat berfungsi secara penuh dan efektif ${ }^{32}$.

Bimbingan dan pembinaan disiplin peserta didik bertujuan agar perkembangan peserta didik baik dalam aspek pribadi maupun sosial bisa semakin meningkat. Disamping itu bimbingan dan pembinaan kedisiplinan peserta didik juga berfungsi membangun kepribadian peserta didik untuk selalu mentaati peraturan dan terbiasa dengan kehidupan yang teratur dan terarah. Hal ini sesuai dengan tujuan layanan bimbingan yaitu untuk membantu peserta didik agar dapat mencapai tujuan-tujuan perkembangan meliputi aspek pribadi, sosial, belajar dan karir bimbingan pribadi; social dalam mewujudkan pribadi yang taqwa, mandiri dan bertanggung jawab. Bimbingan belajar; dimaksudkan untuk mencapai tujuan dan tugas perkembangan pendidikan, konselor dimaksudkan untuk mewujudkan pribadi produktif ${ }^{33}$. Hal ini juga sesuai dengan fungsi dari kedisiplinan yaitu membangun kepribadian, terciptanya lingkungan kondusif, melatih kepribadian, dan menata kehidupan bersama.

Kegiatan bimbingan di MTs. Maarif NU dilaksanakan melalui program layanan bimbingan konseling. Sedangkan untuk pembinaan disiplin peserta didik melalui berbagai kegiatan seperti PKS dan Polcil, Budaya 5S (Senyum, sapa,

\footnotetext{
${ }^{31}$ Oteng Sutisna, Administrasi Pendidikan: Dasar Teoritis Untuk Praktek Profesional / Oteng Sutisna (Angkasa, 1987).66

${ }^{32}$ Dewa Ketut SUKARDI, Pengantar Pelaksanaan Program Bimbingan Dan Konseling Di Sekolah/ Dewa Ketut Sukardi (Jakarta: Rineka Cipta, 2003). 78

${ }^{33}$ Hadari Nawawi, Administrasi pendidikan (Haji Masagung, 1988).89
} 
Salam, Sopan, dan Satun) dan Budaya 3B (Baik, Benar, Berguna), Refleksi dan Muhasabah. Berbagai kegiatan tersebut bertujuan untuk membantu terciptanya lingkungan madrasah berdisiplinan, pembina bersih, rapi, dan kondusif sehingga KBM dapat berjalan lancar dan efektif serta sebagai salah satu bentuk aplikasi nilai-nilai Islam. Sedangkan untuk Refleksi dan Muhasabah bertujuan untuk membiasakan dan melatih peserta didik untuk selalu muhasabah dalam keseharian telah di lakukan dalam satu hari tersebut dengan harapan kedepan tidak akan mengulangi dan mengetahui perbuatan-perbuatan yang baik dalam satu hari.

Kegiatan bimbingan dan pembinaan kedisiplinan di MTs. Ma’arif NU secara tidak langsung dapat mempengaruhi kecerdasan intelektual dan emosional peserta didik. Seperti faktor yang mempengaruhi inteligensi yaitu pembawaan dan pembentukan dari lingkungan. Pembawaan adalah sifat yang dibawa dari lahir. Mengingat sifat yang dibawa oleh setiap peserta didik di MTs. Ma'arif NU itu berbeda-beda, maka kegiatan bimbingan dan kedisiplinan itu diadakan. Setiap peserta didik akan bersama-sama menciptakan lingkungan madrasah yang kondusif, mentaati setiap peraturan dan seluruh peserta didik diwajibkan untuk selalu bertanggungjawab.

Pembentukan adalah segala keadaan diluar diri seseorang yang mempengaruhi perkembangan intelegensi ${ }^{34}$. Pembentukan di MTs. Ma'arif NU merupakan pembentukan yang sengaja yang dilakukan di madrasah yaitu berupa pengadaan layanan bimbingan dan disiplin peserta didik yang sengaja membentuk kepribadian disiplin dan bertanggung jawab.

Adapun kegiatan yang mampu mempengaruhi kecerdasan emosional peserta didik yaitu Refleksi dan Mubasabah yang dilaksanakan setiap Ahad Pon dalam bentuk kegiatan keagamaan dan pengajian yang bertujuan membiasakan dan melatih peserta didik untuk selalu muhasabah dalam keseharian telah di lakukan dalam satu hari tersebut harapan kedepan tidak akan mengulangi dan mengetahui perbuatan-perbuatan yang baik. Hal ini sesuai dengan teori mengenai cara

34Purwanto Ngalim, Ilmu Pendidikan Teoritis dan Praktis, 17th ed. (Bandung: Remaja Rosdakarya, 2006).121 
meningkatkan kecerdasan emosional yaitu mengenali emosi yang dirasakan, mengelola emosi, memotivasi diri sendiri dan introspeksi ${ }^{35}$.

Kegiatan pencatatan dan pelaporan peserta didik di MTs. Ma'arif NU dilaksanakan oleh wali kelas. Wali kelas memiliki buku catatan khusus per individu peserta didik yang berisi catatan guru tentang perkembangan peserta didik setiap hari. Disamping itu, pencatatan hasil belajar peserta didik dikelas (kurikuler) maupun diluar kelas (ekstrakurikuler) beserta deskripsi hasil belajar dicatat dalam buku Raport. Pencatatan tersebut akan dilaporkan kepada wali murid pada akhir semester. Hal ini sesuai dengan teori Eka Prihatin yang menyebutkan bahwa kegiatan pencatatan dan pelaporan dimulai sejak peserta didik diterima di madrasah tersebut. Pencataan tentang kondisi peserta didik perlu dilakukan agar pihak lembaga dapat memberikan bimbingan yang optimal pada peserta didik. Sedangkan pelaporan dilakukan sebagai wujud tanggung jawab lembaga agar pihak-pihak terkait dapat mengetahui perkembangan peserta didik di lembaga terkait.

Peserta didik yang sudah menyelesaikan pendidikan di MTs. Ma'arif NU dengan mengikuti ujian praktek, ujian lisan, dan ujian akhir madrasah maka dikatan lulus dan kembali pada orang tua masing-masing. Peserta didik yang sudah dinyatakan lulus akan mendapatkan Surat Tanda Tamat belajar dan Ijazah dari MTs. Ma'arif NU. Hal ini sesuai dengan kegiatan paling akhir dari manajemen peserta didik yaitu kelulusan yang mana kelulusan adalah pernyataan dari lembaga pendidikan tentang telah diselesaikannya program pendidikan yang harus diikuti oleh peserta didik. Setelah peserta didik selesai mengikuti seluruh program pendidikan di suatu lembaga pendidikan dan berhasil lulus dan ujian akhir, maka kepada peserta didik itu diberikan surat keterangan lulus atau sertifikat. Umumnya surat keterangan tersebut sering disebut ijazah atau Surat Tanda Tamat Belajar (STTB).

${ }^{35}$ Makmun MUBAYIDH, Kecerdasan Dan Kesehatan Emosional Anak: Makmun Mubayidh Jakarta: Pustaka Alkanisan, 2006), 23 


\section{Kesimpulan}

Rekrutmen peserta didik baru di MTs. Ma'arif NU menggunakan pendekatan active recruit dan penyelenggaraan Matsama, Active recruit dilakukan dengan Walksins; calon peserta didik baru datang ke MTs. Ma'arif NU dan mendaftarkan diri, dan Write-ins; calon peserta didik baru beserta orang tua menulis formulir pendaftaran. Matsama dilaksanakan untuk mengembangkan kognisi peserta didik baru dalam hal kemampuan berpikir divergen dan konvergen. Penempatan peserta didik di MTs. Ma'arif NU dilaksanakan berdasarkan abjad and finger print system. Abjad system digunakan untuk penempatan pada pembelajaran di kelas (intrakurikuler). Pada abjad system dilakukan The Dual Progress Plan Grouping yakni membagi peserta didik menjadi beberapa kelompok yang memiliki kecerdasan yang heterogen yang kemudian diampu oleh seorang guru (Self-Contained Classroom). Sedangkan finger print system digunakan untuk penempatan peserta didik pada pengembangan bakat dan minat (ekstrakurikuler). Pengembangan kepeserta didikan dalam pengembangan kecerdasan intelektual emosional dilaksanakan melalui 3 dasar kegiatan pendidikan, yaitu intrakurikuler, kokurikuler dan ekstrakurikuler. (a) intrakurikuler; pembelajaran dalam kelas, (b) kokurikuler; pemberian PR dan penugasan peserta didik berbasis produk, (c) ekstrakurikuler; les olimpiade sains kuark, matematika, bahasa Inggris, program bimbingan, kedisiplinan, refleksi, dan muhasabah.

\section{Daftar Rujukan}

Anwar, Sudirman. Management Of Student Development. Tembilahan: Indragiri TM, 2015.

Aqib, Zainal. Menjadi guru profesional berstandar nasional: memuat standar nasional pendidikan UURI no. 20/2003 (Sisdiknas), UURI no. 14/2005 (guru dan dosen), PPRI no. 19/2005 (standar nasional pendidikan), PPRI no. 74/2008 (guru), delapan permendiknas (standar nasional pendidikan), Permendiknas no. 10/2009 (sertifikasi bagi guru dalam jabatan), Permendiknas no. 36/2007 (penyaluran tunjangan profesi bagi guru), Permendiknas no. 39/2008 (pembinaan kesiswaan). Yrama Widya, 2009.

Arifin, Zainal. “Evaluasi Pembelajaran.” Bandung: Remaja Rosdakarya, 2009. 
Arikunto, Suharsini. Organisasi dan administrasi: pendidikan teknologi dan kejuruan. Jakarta: Rajawali, 1990.

B. Uno, Hamzah. Perencanaan Pembelajaran. Jakarta: Bumi Aksara, 2007.

Dick, W., L. Carey, and J.O. Carey. The Systematic Design of Instruction. Vital $\begin{array}{lllll}\text { Source } & \text { (for } \quad \text { Pearson) } & \text { VST }\end{array}$ https://books.google.co.id/books?id=XIjNjgEACAAJ.

Eliasa, Eva Imania, Sunaryo Kartadinata, Ilfiandra Ilfiandra, and Juntika Nurihsan. "Pedagogy of Peacefulness as an Effort of Peaceful Education at School." Indonesian Journal of Educational Counseling, Vol. 3, No. 2, 2019.

Farid, Muhammad, and Daryanto. Konsep Dasar Manajemen Pendidikan Di Sekolah. Yogjakarta: Gava Media, 2013.

Goleman, Daniel. Emotional Intelligence: Why It Can Matter More Than IQ. New York : Toronto: Random House Publishing Group, 2012.

Gunawan, Ary. Administasi Sekolah (Administrasi Pendidikan Mikro). Jakarta: Rineka Cipta, 2002.

Hasanah, Mizanul. "Rekrutmen Dan Seleksi Tenaga Pendidikan (Guru) Untuk Meningkatkan Kualitas Pendidikan Di SMA Unggulan Berbasis Pesantren Amanatul Ummah Pacet.” Al-Tarbawi Al-Haditsah: Jurnal Pendidikan Islam Vol. 5, No. 1, 2020.

Hen, Meirav, and Marina Goroshit. "Academic Procrastination, Emotional Intelligence, Academic Self-Efficacy, and GPA: A Comparison Between Students With and Without Learning Disabilities." Journal of Learning Disabilities, Vol. 47, No. 2, 2014.

Imron, Ali. Manajemen Peserta Didik Berbasis Sekolah. Bandung: Bumi Aksa, 2012. Krisbiyanto, Achmad. "Efektifitas Kepemimpinan Kepala Madrasah Terhadap Mutu Pendidikan MTsN 2 Mojokerto." Nidhomul Haq: Jurnal Manajemen Pendidikan Islam, Vol. 4, No. 1, 2019.

Maarif, Muhammad Anas, Muhammad Husnur Rofiq, and Nur Silva Nabila. "Pendidikan Pesantren Berbasis Multiple Intellegences (Kecerdasan Majemuk)." Tafkir: Interdisciplinary Journal of Islamic Education, Vol. 1, No. $1,2020$. 
Majid, Abdul. Belajar Dan Pembelajaran Pendidikan Agama Islam. 2nd ed. Bandung: Remaja Rosdakarya, 2014.

Matwaya, Arin Muflichatul, and Ahmad Zahro. "Konsep Spiritual Quotient Menurut

Danah Zohar Dan Ian Marshall Dalam Perspektif Pendidikan Islam.” Attadrib: Jurnal Pendidikan Guru Madrasah Ibtidaiyah, Vol. 3, No. 2, 2020.

Mubayidh, Makmun. Kecerdasan Dan Kesehatan Emosional Anak: Makmun Mubayidh. Jakarta: Pustaka Alkanisan, 2006.

Mudlofir, Ali. Pendidik profesional: konsep, strategi, dan aplikasinya dalam peningkatan mutu pendidikan di Indonesia. Jakarta: RajaGrafindo Persada, 2012.

Nawawi, Hadari. Administrasi pendidikan. Haji Masagung, 1988.

Ngalim, Purwanto. Ilmu Pendidikan Teoritis dan Praktis. 17 th ed. Bandung: Remaja Rosdakarya, 2006.

Prihatin, Eka. Manajemen Peserta Didik. Bandung, Indonesia: Alfabeta, 2011.

Rivai, Veithzal. Manajemen sumber daya manusia untuk perusahaan: dari teori ke praktik. Rajawali Pers, 2009.

Riyadi, Ivan. "Integrasi Nilai-Nilai Kecerdasan Emosional Dalam Kurikulum Pendidikan Agama Islam Di Sma: Perspektif Daniel Goleman.” Hunafa: Jurnal Studia Islamika, Vol. 12, No. 1, 2015.

Sabri, Ahmad. Strategi Belajar Mengajar Micro Teaching/Ahmad Sabri. Jakarta: Quantum Teaching, 2010.

Sj, Diana Susilawati, Muhammad Anas Maarif, and Afif Zamroni. "Strategi Pengembangan Program Pembelajaran Pendidikan Agama Islam Sekolah: The Development Strategy of Islamic Religious Education Learning Programs.” Tafkir: Interdisciplinary Journal of Islamic Education, Vol. 2, No. 1, 2021.

Slameto. Belajar dan faktor-faktor yang mempengaruhinya. Jakarta: Bina Aksara, 1988.

Soetopo, Hendyat. Pengantar Operasional Administrasi Pendidikan. Jakarta: Usaha Nasional, 1982.

SUKARDI, Dewa Ketut. Pengantar Pelaksanaan Program Bimbingan Dan Konseling Di Sekolah/ Dewa Ketut Sukardi. Jakarta: Rineka Cipta, 2003. 
Sundari, Ayu. "Manajemen Kegiatan Ekstrakurikuler Dalam Meningkatkan Prestasi Non Akademik Siswa." Munaddhomah: Jurnal Manajemen Pendidikan Islam, Vol. 2, No. 1, 2021.

Sutisna, Oteng. Administrasi Pendidikan: Dasar Teoritis Untuk Praktek Profesional / Oteng Sutisna. Angkasa, 1987.

Wibowo, Agus. Manajemen Pendidikan Karakter Di Sekolah: Konsep Dan Pratik Implementasi. Semarang: Diterbitkan atas kerjasama Fak Tarbiyah IAIN Walisongo Pustaka Pelajar, 2013.

Wibowo, Agus and Gunawan. Pendidikan karakter berbasis kearifan lokal di sekolah: konsep, strategi, dan implementasi. Yogyakarta: Pustaka Pelajar, 2015.

Yarso, Wenefrida, Yohanes Bahari, and Yusuf Ibrahim. "Penanggulangan Kenakalan Siswa Kelas Xi Jurusan Pemasaran Sekolah Menengah Kejuruan Bhineka Tunggal Ika Pontianak." Jurnal Pendidikan dan Pembelajaran Khatulistiwa, Vol.2, No. 6, 2013. 